\title{
The Effect of Air Distribution System towards Indoor Air Quality (Case Study: Auditorium of Phinisi Tower)
}

\author{
Yetti Yunianti Ishak, ${ }^{\mathrm{a}^{*}}$ Baharuddin Hamzah, ${ }^{\mathrm{b}}$ Rosady Mulyadi, ${ }^{\mathrm{c}}$ \\ ${ }^{a}$ Department of Architecture, Engineering Faculty, Hasanuddin University. Email: yettiyunianti@ gmail.com \\ bepartment of Architecture, Engineering Faculty, Hasanuddin University. Email: baharsyah@unhas.ac.id \\ 'Department of Architecture, Engineering Faculty, Hasanuddin University. Email: rosadyd51rm@gmail.com
}

\begin{abstract}
This research aims to analyze the type of air distribution system in auditorium, the effect on air quality in the room, as well as the design of appropriate air distribution systems for the auditorium to improve air quality. This study used quantitative methods, by measuring the $\mathrm{CO}_{2}$ gas concentration, air temperature and humidity in room, using the HT-2000 data logger. The measurements were conducted when the room is empty and when the room is occupied. After that, the analysis and simulation were done by using ANSYS-Fluent software. Displacement ventilation distribution system was designed by calculating the total amount of cooling load, the required air flow rate, the air supply temperature, and the return air temperature. The analysis result showed that the mixing ventilation distribution system in the auditorium could not resolve air quality in the room. Based on that results when the room is inhabited, it was known that the lowest and highest value for $\mathrm{CO}_{2}$ concentration level was $973 \mathrm{ppm}$ and $1993 \mathrm{ppm}$; for air temperature of $20.5^{\circ} \mathrm{C}$ and $28,6^{\circ} \mathrm{C}$; while the room air humidity of $49 \%$ and $71 \%$. The displacement ventilation distribution system was designed to overcome the air quality problem in the chamber by air temperature setting was $24^{\circ} \mathrm{C}$, the air supply velocity coming from the diffuser was $0.25 \mathrm{~m} / \mathrm{s}$, the total surface area of the diffuser was $20.7 \mathrm{~m}^{2}$, and the flow pattern of moving air from the bottom to top of the room.
\end{abstract}

Keywords: Ansys Fluent, carbondioxide, displacement ventilation, mixing ventilation

\section{Introduction}

Auditorium is one of the rooms in Phinisi Tower, Makassar City. This room can accommodate up to 472 visitors. The intensity of the auditorium usage is quite high, therefore, the comfortableness factor of auditorium users is one of the important things to be noted. The condition of this room with no less visitors, got the auditorium in air pollution problems. Carbondioixide (CO2) gas accumulation can occur as a result of the visitors respiration's process when the activity takes place in the room.Hence, the auditorium requires special treat in order to obtain a good air quality. Because unlike the other rooms, opening windows for fresh air intake can't be able to get. In addition, air quality is also closely related to the health of users / visitors.

Sufficient air quality in the auditorium can actually be obtained through a good air distribution system within a large area, especially in the visitor area, to reduce the of pollutants in the form of $\mathrm{CO}_{2}$ gas.

${ }^{*}$ Corresponding author. Tel.: +62-813-402-00293

Sipil Raya Ruko No. 11 Antang

Makassar, Indonesia, 90235
Therefore, research on the air distribution system and its effect on air quality levels in the auditorium, it is important to be held. This is done in order to obtain a solution in the form of design of air distribution system in the appropriate space for auditorium. The design of air distribution system is expected to be able to supply a fresh air with a comfortable level of air flow, while reducing or avoiding $\mathrm{CO} 2$ gas, especially in the area of the audiences. The design of the air distribution system is also ultimately expected to be an input to the future auditorium development plan.

This research on thermal comfort analysis and indoor air quality (IAQ) in theater space using mechanical ventilation, has also been done by Kavgic M., et al. [1]. The objectives of the study were to analyze indoor air quality levels and thermal comfort in the theater, and to identify improvements that could be made. The parameter indicators in this study are Predicted Mean Vote (PMV) Index, Percentage People of Dissatisfied (PPD) Index, Draft Rrate Index, Mean Age of Air (AGE) and Ventilation Effectiveness (Ev). Based on the results of monitoring and evaluation, most of the environmental parameters within the theatrical building under study are within the thermal 
comfort and IAQ standards. However, there are some things that need attention such as: the energy consumption for large circulation, therefore the operation of $\mathrm{CO}_{2}$ control system for ventilation system can be mixed in the existing system.

The research on distribution systems utilizing mechanical ventilation and its effect on thermal amenities, has been done by Fong, M.L., et al. [2]. The purpose of this study is to determine the model of ventilation design that is able to create a neutral temperature and can achieve thermal comfort with optimal energy efficiency. The dependent variable found on this research is thermal comfort in the classroom, while the independent variable is a model of ventilation design. Parameter indicators in this study are Predicted Mean Vote (PMV) Index, relative humidity (RH), temperature, and air change per hour $(\mathrm{ACH})$. The results of this study indicated that for a classroom with a capacity of 42 people, Stratum ventilation can provide satisfactory results at the thermal comfort level with the highest energy savings compared to other types of mechanical ventilation. After that was displacement ventilation and the last was mixing ventilation.

\section{Research objectives}

- To analyze the type of air distribution system contained in the auditorium of the Phinisi Tower.

- To evaluate the effect of the air distribution system in the auditorium towards the air quality level in the room.

- To design air distribution system in auditorium which can provide air flow in a comfortable space while simultaneously reducing/avoiding the buildup of indoor $\mathrm{CO}_{2}$ gas especially in audience area.

\section{Research method}

\subsection{Location and time of study}

The research location was located in the auditorium, precisely on the $3^{\text {rd }}$ and $4^{\text {th }}$ floors of Phinisi Tower, Universitas Negeri Makassar, located in Jalan Andi Pangeran Pettarani, Makassar City. The time of research from collecting to data processing were done for 3 months, started from September to November 2017.

\subsection{Data source}

Indoor Air Quality (IAQ) is the condition of indoor air content that can affect occupant health and comfort [3]. According to ASHRAE the maximum limit of indoor $\mathrm{CO}_{2}$ gas should not pass $1,000 \mathrm{ppm}$ to achieve comfortable room state [4].

In general, air distribution system is divided into 2 types, namely: (1) Mixing Ventilation; an air distribution system where fresh air is supplied in such a way that the entire air volume in the chamber is fully mixed [5]; and (2) Displacement Ventilation; an air distribution system by supplying fresh air into the room at low speed and also usually at low altitudes [5].

According to SNI 03-6572-2001 [6], to maintain comfortable conditions, the air velocity that falls on the head should not be greater than $0.25 \mathrm{~m} / \mathrm{s}$ and preferably less than $0.15 \mathrm{~m} / \mathrm{s}$.

In addition to secondary data in the form of information derived from various literatures, primary data collection is also obtained from the results of direct measurement at the study sites, including:

- Auditorium room dimension, as well as stage placement and audience seats.

- Airflow rate

- Air temperature

- Humidity

- Level of concentration of $\mathrm{CO}_{2}$ gas

\subsection{Research design}

The method used in this research is quantitative research method. On its application, research is done through several stages. The first stage is the dimension of the auditorium room dimension including: dimension as well as the placement of the stage and audience seats, the number and the inlet placement, the outlet and the point of light, and the measurement of temperature and movement of air originating directly from the source, from inlet and outlet.

The second stage, is a measurement of $\mathrm{CO}_{2}$ gas concentration level, air temperature and humidity when the room is empty, without any activity taking place in it. At this stage the measurements were made at six predetermined sets of times, (1) when the HVAC element such as the inlet, outlet and the lamp is not turned on at all; and (2) after the inlet, the outlet and the lights were turned on and the room had been idle for \pm 1 hour. This was done to determine the level of air quality when the auditorium is empty, before and after the inlet, outlet and room lights are turned on

The third stage, is a measurement of $\mathrm{CO}_{2}$ gas concentration level, air temperature and humidity when the activity takes place in the auditorium at six predetermined points. Due to the limited number of equipment available, the data collection is done 2 times in 2 different activities. In the first activity, the measurements of $\mathrm{CO}_{2}$, air temperature and humidity concentration levels were performed at 3 point measurements in 3 groups of audience seats located in the front row (point A, B, and C). Furthermore, in the second activity, the measurements of $\mathrm{CO}_{2}$, air temperature and humidity concentration levels were performed at 3 point measurements in 3 groups of audience seats located in the back row $(\mathrm{D}, \mathrm{E}$, and $\mathrm{F}$ measurements).

After the measurement done, next step is to make the simulation based on the data of the primary data collection that had been done. Simulation using mixing ventilation method that is suitable with existing auditorium condition. 
After that, design the distribution system of displacement ventilation through calculation and simulate the result of the calculation.

The process of data analysis was done by analyzing the measurement result of the existing distribution system (mixing ventilation) with the result of displacement ventilation design and the standard used.

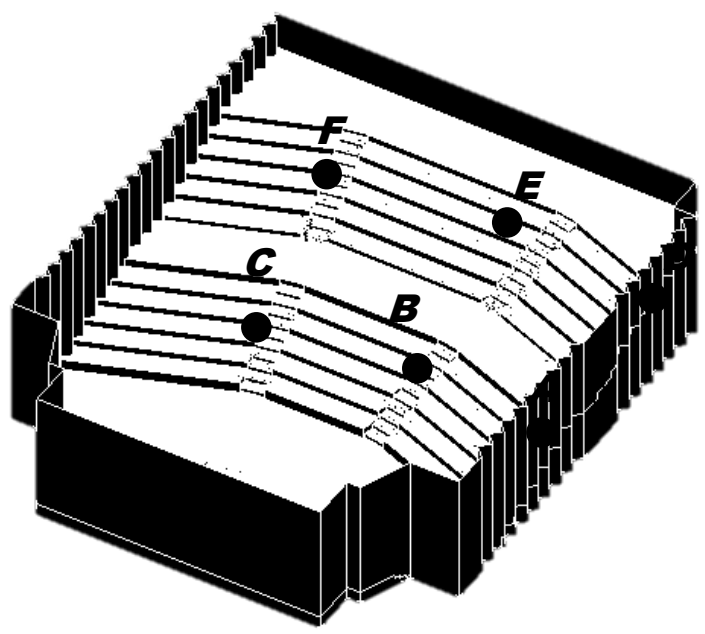

Figure 1. Position of measurement points in auditorium

\section{Data analysis method}

Analysis of data used was correlational analysis which was trying to find a relationship or influence between several variables.

- To determine the type of air distribution system used in the auditorium, the analysis process is carried out by comparing the measurements of the $\mathrm{CO}_{2}$ gas concentration level, air temperature and humidity when the room is empty, without occupants and no activity taking place in it. The measurements made before and after the inlet, the outlet and the light were turned on; then summarized, analyzed and compared with the characteristics of mixing ventilation distribution system.

- To know the level of air quality in the auditorium, measurements of $\mathrm{CO}_{2}$ gas concentration, air temperature and humidity level during the auditorium activity. The results of these measurements were then summarized and analyzed and then compared with the standards, so it was known whether the current air distribution system can meet the air quality required by visitors within the auditorium.

- To obtain the design of the displacement ventilation distribution system, calculations were made to the total amount of cooling loads, the required air flow rate, the air supply temperature, and the air-return temperature. The results of these calculations are then analyzed to obtain the dimensions, number of diffuser points, and room temperature required and in accordance with the standards of comfort.

\section{Research result}

\subsection{The analyze of air distribution system used in the auditorium}

Identification of air distribution system was done by measuring $\mathrm{CO}_{2}$, air temperature and humidity in twice, namely: (1) when inlet, outlet and lamps were not turned on; and (2) the inlet, the outlet and the lights were turned on, then the room was silenced for 1 hour.

The results of data collection at this stage can be seen as the following table.

Table 1. The measurement's result of $\mathrm{CO}_{2}$ gas concentration level, air temperature and humidity in auditorium, before and after the inlet, the outlet and the light were turned on

\begin{tabular}{ccccccc}
\hline \multirow{2}{*}{\begin{tabular}{c} 
Measurement $\begin{array}{c}\mathrm{CO}_{2} \text { Concentration } \\
\text { points }\end{array}$ \\
\cline { 2 - 6 }
\end{tabular}} & $\begin{array}{c}\text { Bevel }(\mathrm{ppm}) \\
\text { Before }\end{array}$ & $\begin{array}{c}\text { Afemperature } \\
\left({ }^{\circ} \mathrm{C}\right)\end{array}$ & \multicolumn{2}{c}{ Humadity $(\%)$} \\
\hline A & 537 & 461 & 31.1 & 26.7 & 64.0 & 63.0 \\
B & 551 & 463 & 32.0 & 26.7 & 64.0 & 63.0 \\
C & 573 & 459 & 30.7 & 27.3 & 63.9 & 63.0 \\
D & 509 & 462 & 31.9 & 27.4 & 64.3 & 63.3 \\
E & 508 & 460 & 31.8 & 27.4 & 64.3 & 63.2 \\
F & 513 & 463 & 31.6 & 26.7 & 64.2 & 63.0 \\
\hline Range & 65 & 4 & 1.3 & 0.7 & 0.4 & 0.3 \\
\hline
\end{tabular}

From the table above, it can be seen that when the HVAC element especially diffuser and exhaust has not been turned on, the value of $\mathrm{CO}_{2}$, air temperature, and humidity contained in the six measuring points tend to vary greatly. This can be seen from the range of values that occur between the maximum value and the minimum value with the condition of the same room. For indoor $\mathrm{CO}_{2}$, the value range reaches 65 points; for indoor air temperature reached 1.3 points; while for air humidity reaches 0.4 points.

Conversely, after the HVAC elements, especially the diffuser and the exhaust were turned on, the variation of that value becomes smaller. $\mathrm{CO}_{2}$, temperature and humidity levels tend to be evenly distributed at each measuring point in the auditorium.

In addition to the above measurements, data retrieval of temperature and air velocity originating from the air supply source (supply air) and also at the point of exit of air from the room (return air), also done. This data will be input when performing computerized simulations.

The measurements made on the inlet and outlet contained in the auditorium are: for inlet, the temperature and velocity of the airflow contained at that point is $20^{\circ} \mathrm{C}$ and $2.7 \mathrm{~m} / \mathrm{s}$; while for the outlet, the temperature and velocity of the airflow at that point are $22^{\circ} \mathrm{C}$ and $1.6 \mathrm{~m} / \mathrm{s}$. The temperature and velocity of the airflow were considered constant at all inlet and outlet points, since the ventilation system used is a mechanical. 


\subsection{Air quality level in auditorium}

To determine the level of air quality during the activity in the auditorium, measurements of $\mathrm{CO}_{2}$ levels, temperature and humidity of the room in the six-point group of audience seats in the auditorium. However, due to the limited equipment, the data collection was done in 2 different activities.

The first activity was held on the first Sunday of November, 2017. The number of visitors during the activity took place around 370 people (filled space $\pm 80 \%$ ). The activity lasted for 2.5 hours from 09.30 WITA until 12.00 WITA. The data were collected at 3 points of measurement for the group of chairs located at the front of the room, at points A', B', and C'. Recording of the measurement results was done every 5 minutes during the activity.
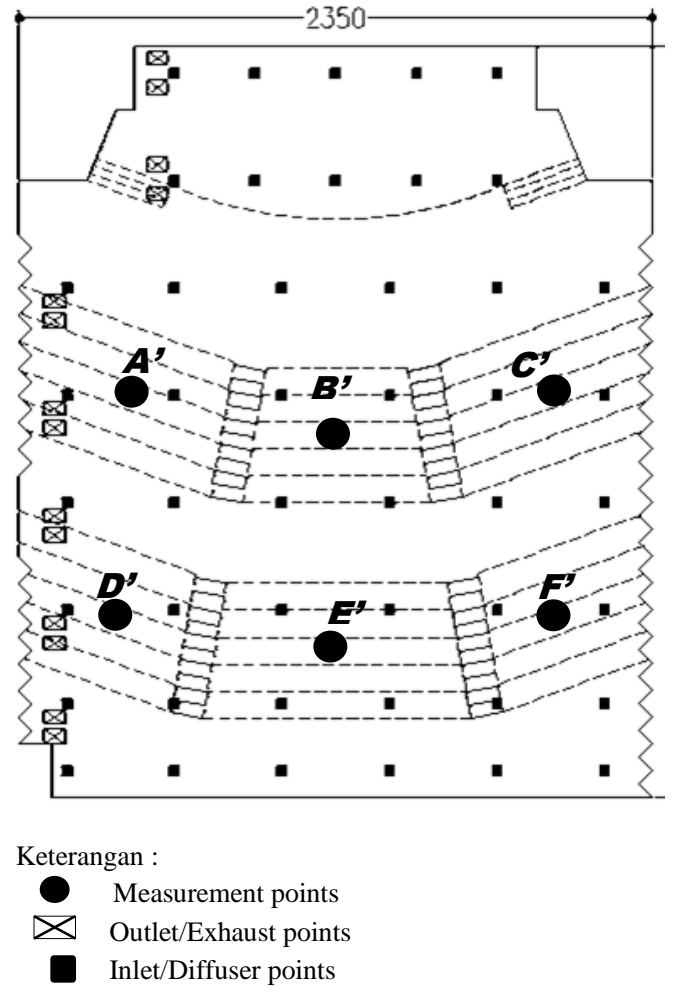

Figure 2. Position of measurement points, inlet points and oulet points during the activity took place in auditorium

The second activity was held on the second Sunday of November, 2017. The number of visitors in this activity is about 280 people (the room is filled $\pm 60 \%$ ). The activity lasted for 3 hours from 09.20 WITA until 12.20 WITA. There was a break time in the middle of the activity that is at 9:50 am until 10:15 am, where visitors were directed out of the room to take a break and enjoy a snack. The data were collected at 3 point measurements for the group of chairs located at the back of the room, at point D', E', and F'. Recording of the measurement results was done every 5 minutes during the activity.
5.2.1. Analysis of the results of $\mathrm{CO}_{2}$ gas concentration level measurements during activities in the auditorium

The following two figures (Figs. 3 and 4) show that average levels of $\mathrm{CO}_{2}$ are above the threshold permitted by ASHRAE.

Gas $\mathrm{CO}_{2}(\mathrm{ppm})$

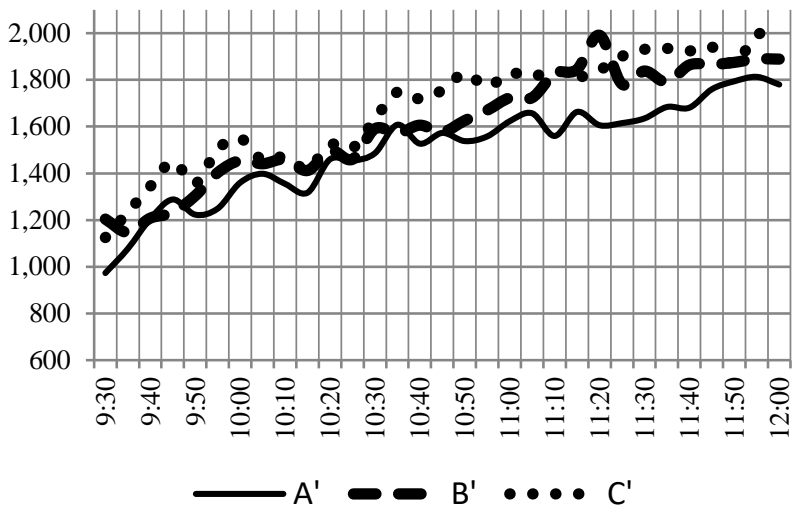

Figure 3. The measurement result of $\mathrm{CO}_{2}$ gas concentration level at points A', B' dan C' during the first activity took place in auditorium

Gas $\mathrm{CO}_{2}(\mathrm{ppm})$

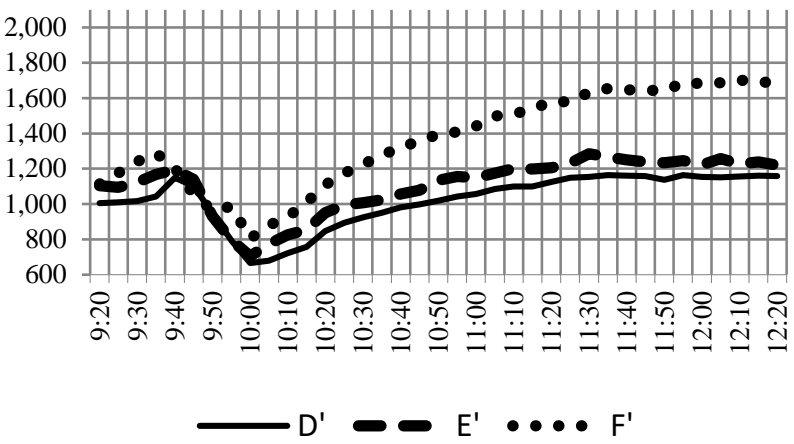

Figure 4. The measurement result of $\mathrm{CO}_{2}$ gas concentration level at points D', E' dan F' during the second activity took place in auditorium

The maximum value of $\mathrm{CO}_{2}$ in a room should not exceed $1000 \mathrm{ppm}$ in order to get a good quality air. However, if the results of the six points measurements were compared, it will be seen that at the measuring point $\mathrm{A}^{\prime}$ and the mean $\mathrm{D}^{\prime}$ point have a concentration level of $\mathrm{CO}_{2}$ gas below the point $\mathrm{B}^{\prime}$ and the measuring point $\mathrm{E}^{\prime}$. The concentration level of $\mathrm{CO}_{2}$ gas at point $\mathrm{B}^{\prime}$ and point $\mathrm{E}^{\prime}$ is below the measuring point $\mathrm{C}^{\prime}$ and point $\mathrm{F}^{\prime}$. The difference that occurs can be caused by the position of the measuring point to the location of the exhaust that was only found on one side of the room (Fig. 2). In first activity and for the bench group located in the front, the measuring point $\mathrm{A}^{\prime}$ which was closest to the exhaust, has a concentration level $\mathrm{CO}_{2}$ gas is the lowest compared to 2 other measuring points; after that followed by point B' which is in the center of the room; and point $\mathrm{C}^{\prime}$ which is farthest from the exhaust position, has the highest level of $\mathrm{CO}_{2}$ concentration. Similarly to activity II, for the bench group located at the 
back. The measurement point $\mathrm{D}^{\prime}$ which is closest to the exhaust, has the lowest concentration of $\mathrm{CO}_{2}$ gas than the other 2 points; after that followed by point $\mathrm{E}^{\prime}$ which is in the center of the room; and point $\mathrm{F}^{\prime}$ which is farthest away from the exhaust position, has the highest level of $\mathrm{CO}_{2}$ concentration.

Table 2. The measurement result of $\mathrm{CO}_{2}$ gas concentration level during activities in auditorium

\begin{tabular}{cccccc}
\hline \multirow{2}{*}{$\begin{array}{c}\text { Measurement } \\
\text { points }\end{array}$} & \multicolumn{5}{c}{$\mathrm{CO}_{2}$ CONCENTRATION (PPM) } \\
\cline { 2 - 5 } Min & Time & Max & Time & \\
\hline \multicolumn{2}{c}{ ACTIVITY I } & & & & \\
A $^{\prime}$ & 973 & $9.30 \mathrm{am}$ & 1813 & $11.55 \mathrm{am}$ & 1501 \\
B' & 1147 & $9.35 \mathrm{am}$ & 1991 & $11.20 \mathrm{am}$ & 1605 \\
C' $^{\prime}$ & 1125 & $9.30 \mathrm{am}$ & 1993 & $11.55 \mathrm{am}$ & 1678 \\
ACTIVITY II & & & & \\
D' & 848 & $10.20 \mathrm{am}$ & 1164 & $11.55 \mathrm{am}$ & 1075 \\
E' & 951 & $10.20 \mathrm{am}$ & 1285 & $11.30 \mathrm{am}$ & 1164 \\
F' & 1054 & $9.45 \mathrm{am}$ & 1702 & $12.10 \mathrm{am}$ & 1447 \\
\hline
\end{tabular}

There are many things that can affect the level of $\mathrm{CO}_{2}$ concentration in the room, such as the number of visitors who are around the measuring point. At the time of activity, visitors are free to choose their own seats in the auditorium, so that the spread of visitors in the auditorium is uneven. In addition, visitor activity also influences the variation of $\mathrm{CO}_{2}$ gas concentration value at each measuring point. Visitor activity as long as the activities within the auditorium are quite diverse; there are visitors who just sit quietly and silently, there are busy talking with a group of other friends, sometimes there are also visitors who come out of the room, some are back again but some are not. Auditory doors are sometimes open and close because the activities of visitors who come out and enter the room also affect the level of $\mathrm{CO}_{2}$ concentration in the room. The $\mathrm{CO}_{2}$ gas concentration value will drop in several points when the door of the room is open, and will go back up when the door of the room is closed. It is shown in Fig. 3. But in general it can be concluded that: (1) the longer the activity is running, the $\mathrm{CO}_{2}$ gas concentration level in the auditorium will also be higher; (2) other than that the seat position against the exhaust also determine the value of $\mathrm{CO}_{2}$ gas concentration. The further away the seat from the exhaust the higher the $\mathrm{CO}_{2}$ gas concentration in that place. Compared to the exhaust, the inlet / diffuser in the auditorium did not appear to have a significant effect on the variation in the value of the measurement results. This is because the number of diffuser / inlet placed on the ceiling is quite large (there are 46 point diffuser / inlet) and located spread in the room.

Temperature $\left({ }^{\circ} \mathrm{C}\right)$

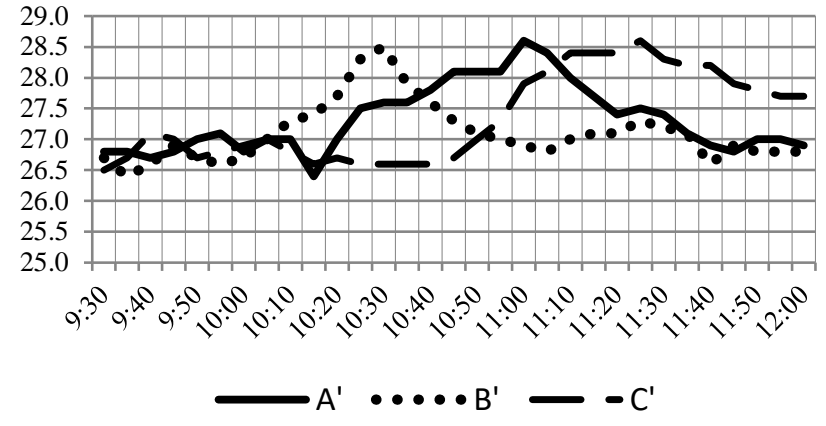

Figure 5. The measurement result of air temperature at points A', B' dan $\mathrm{C}^{\prime}$ during the first activity took place in auditorium

Temperature $\left({ }^{\circ} \mathrm{C}\right)$

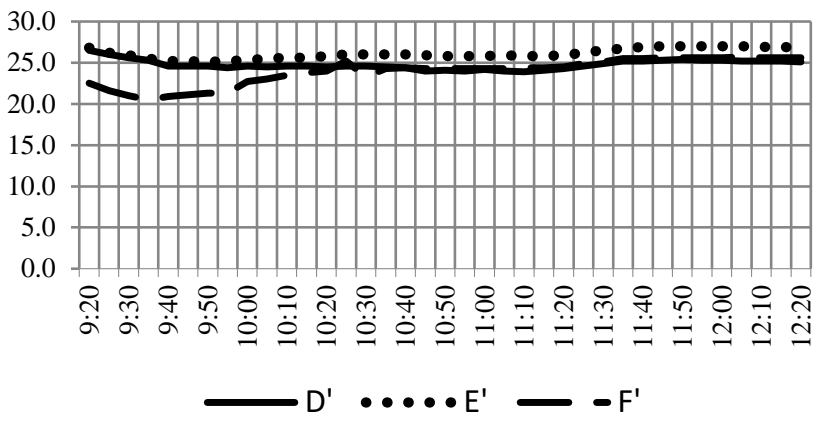

Figure 6. The measurement result of air temperature at points D', E' dan $\mathrm{F}$ ' during the second activity took place in auditorium

\subsubsection{Analysis of the results of temperature measurements during activities in the auditorium}

As shown in Table 1, when the room is empty but the diffuser/inlet, exhaust and lights are turned on in the room; then the temperature will be uniformly mixed in the room with a variation of the value of $0.7^{\circ} \mathrm{C}$ (less than $1^{\circ} \mathrm{C}$ ) in the six measuring points. But at the time of the activity in the auditorium, there are many things that can affect the value of the temperature in the room.

In the first event, the event that took place in the auditorium was the opening ceremony of "Gebyar Aktivitas Fisika" held by students of the Faculty of Mathematics and Natural Sciences UNM. The event took place quite attractively, in the form of dances, choirs, parodies and poetry readings. It was very different when the second activity took place inside the hall. This second activity was an international seminar held by the Language Center. The event took place quietly and seriously. Activities are quite attractive take place only at the opening ceremony that was at the beginning of the activity. After the opening ceremony, the room was vacated briefly from 9:50 am to 10:15 am, where visitors were directed outdoors to enjoy snacks and take a break. After that the seminar activity continued with the activity of the audience more quiet and serious than at the first activity took place. This is what influences the variation of the temperature value in the first 
activity, which is very different from the measurement result in the second activity

Table 3. The measurement result of air temperature during activities in auditorium

\begin{tabular}{cccccr}
\hline $\begin{array}{c}\text { Measure } \\
\text { ment } \\
\text { points }\end{array}$ & Min & Time & Max & Time & Mean \\
\cline { 2 - 5 } Activity I & & & & \\
A' & 26.4 & $10.15 \mathrm{am}$ & 28.6 & $11.00 \mathrm{am}$ & 27.3 \\
B' & 26.4 & $9.35 \mathrm{am}$ & 28.5 & $10.30 \mathrm{am}$ & 27.1 \\
C' & 26.5 & $9.30 \mathrm{am}$ & 28.6 & $11.25 \mathrm{am}$ & 27.3 \\
Activity II & & & & \\
D' & 23.9 & $11.10 \mathrm{am}$ & 26.5 & $9.20 \mathrm{am}$ & 24.8 \\
E' & 25.2 & $9.40-9.45 \mathrm{am}$ & 27.0 & $11.45-12.05 \mathrm{am}$ & 26.2 \\
F' & 20.5 & $9.35 \mathrm{am}$ & 25.7 & $12.05 \mathrm{am}$ & 24.2 \\
\hline
\end{tabular}

In addition to visitor activity, the total visitors are also affected the value of temperature. This is proven in the results of temperature measurements taken during the second activity. At the beginning of the event, at the measuring point $\mathrm{F}^{\prime}$, the audience seats around the measuring point tend to be empty. This causes the lowest temperature level to be at point $\mathrm{F}^{\prime}$ and occurs at the beginning of the activity (Table 3). After the re-activity took place inside the auditorium at $10.15 \mathrm{am}$, the $\mathrm{D}^{\prime}$ and $\mathrm{F}^{\prime}$ group chairs only drew the first and second rows of the group of occupied seats. Another case was in the seat group E', where the seat visitors almost full. This causes the temperature value at the measured point $E^{\prime}$ to be higher than the value of temperature at point $\mathrm{D}^{\prime}$ and the measuring point $\mathrm{F}^{\prime}$. Unlike the case of the first activity. The density of the audience is almost the same in the three groups of seats. So even if there is a variation in the temperature value during the activity (Fig. 5), but if it is averaged, it will be known that the temperature values of the three measuring points (A', B', and C ') are almost identical. This can be seen in the average value of room temperature measurements contained in Table 3 .

\subsubsection{Analysis of the results of humidity measurements during activities in the auditorium}

From the following two figures, we can see that at point $\mathrm{A}^{\prime}$ and point $\mathrm{D}^{\prime}$, which is closest to the exhaust, has a constant humidity value compared to other points. The humidity levels at both points are also on average higher than other measuring points (Table 4). This shows that the role of exhaust in determining the humidity value at one particular measuring point is quite high. The closer to the exhaust the moisture value in the position tends to be more constant and higher. In contrast to the inlet, because of the number and position that spread evenly in the room, the effect on the humidity value is not very noticeable.
Humidity (\%)

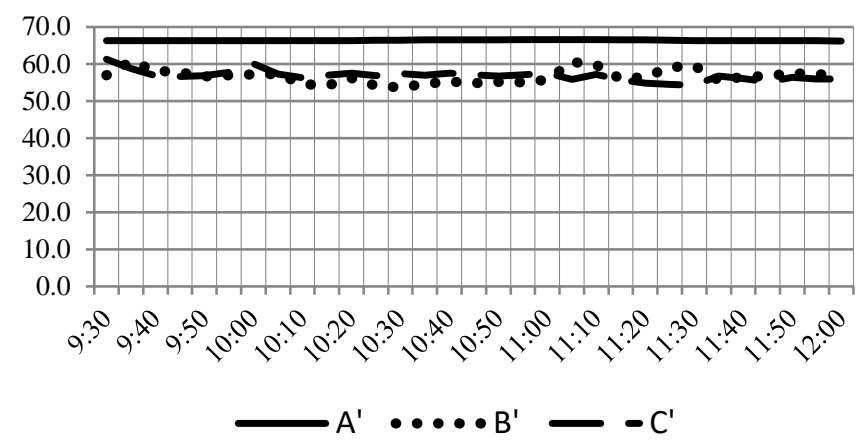

Figure 7. The measurement result of air humadity at points A', B' dan C' during the first activity took place in auditorium

Humidity $(\%)$

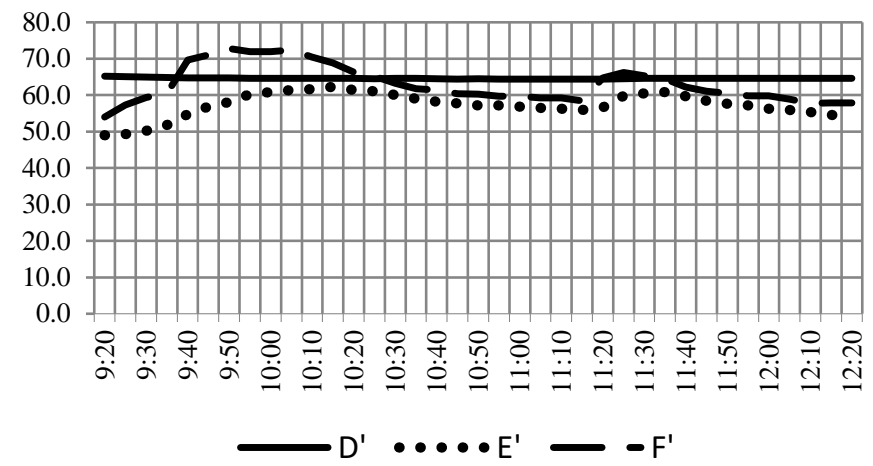

Figure 8. The measurement result of air humadity at points D', E' dan F' during the second activity took place in auditorium

In addition to the position toward the exhaust that is enough to determine the humidity level at a point of measurement, the number of visitors around the measuring point also contributes considerable influence. This can be seen in the result of measurement of humidity level at F' measurement point which is done on activity II. Before the break, the number of visitors seated in the $F^{\prime}$ seat group tends to be empty and the humidity level at that point is quite high. But after the break, the audience seats in the group filled up to 2 front row seats. This results in reduced moisture levels to $58.5 \%$. The value variations occurs, can be caused by the mobility of visitors in the group of chairs.

Table 4. The measurement result of air humadity during activities in auditorium

\begin{tabular}{|c|c|c|c|c|c|}
\hline \multirow{2}{*}{$\begin{array}{c}\text { Measure } \\
\text { ment } \\
\text { points }\end{array}$} & \multicolumn{4}{|c|}{ Humidity (\%) } & \multirow{2}{*}{ Mean } \\
\hline & Min & Time & $\operatorname{Max}$ & Time & \\
\hline \multicolumn{6}{|c|}{ Activity I } \\
\hline $\mathrm{A}^{\prime}$ & 66.2 & $12.00 \mathrm{am}$ & 66.6 & $10.55-11.10 \mathrm{am}$ & 66.4 \\
\hline $\mathrm{B}^{\prime}$ & 53.7 & $10.30 \mathrm{am}$ & 60.7 & $9.35 \mathrm{am}$ & 56.7 \\
\hline$C^{\prime}$ & 54.3 & $11.30 \mathrm{am}$ & 61.3 & $9.30 \mathrm{am}$ & 56.9 \\
\hline \multicolumn{6}{|c|}{ Activity II } \\
\hline D' & 64.4 & $10.45-11.20 \mathrm{am}$ & 65.2 & $9.20 \mathrm{am}$ & 64.6 \\
\hline$E^{\prime}$ & 49.0 & $9.20 \mathrm{am}$ & 61.4 & $10.20 \mathrm{am}$ & 56.7 \\
\hline$F^{\prime}$ & 54.0 & $9.20 \mathrm{am}$ & 71.0 & $9.45 \mathrm{am}$ & 61.4 \\
\hline
\end{tabular}




\subsubsection{The simulation results of the existing auditorium condition (mixing ventilation)}

As previously described, the working principle of mixing ventilation is to supply air into the room at a sufficiently high speed, so that the air contained in the room can be mixed, so that air temperature and humidity tend to be the same in every corner of the room, and the buildup pollutants at a certain point can be avoided.

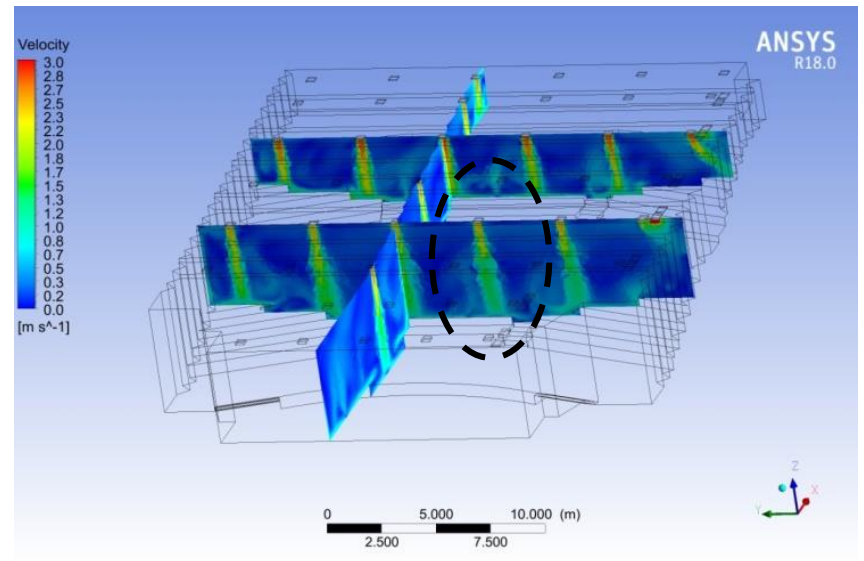

Figure 9. Simulation result of air velocity in auditorium

The same is also shown in the simulation of the existing conditions performed. As shown in Fig. 9, the air coming out of the diffuser (marked with dark circles), is supplied at a fairly high velocity, inducing the already existing air in the room resulting in a mixture of air.

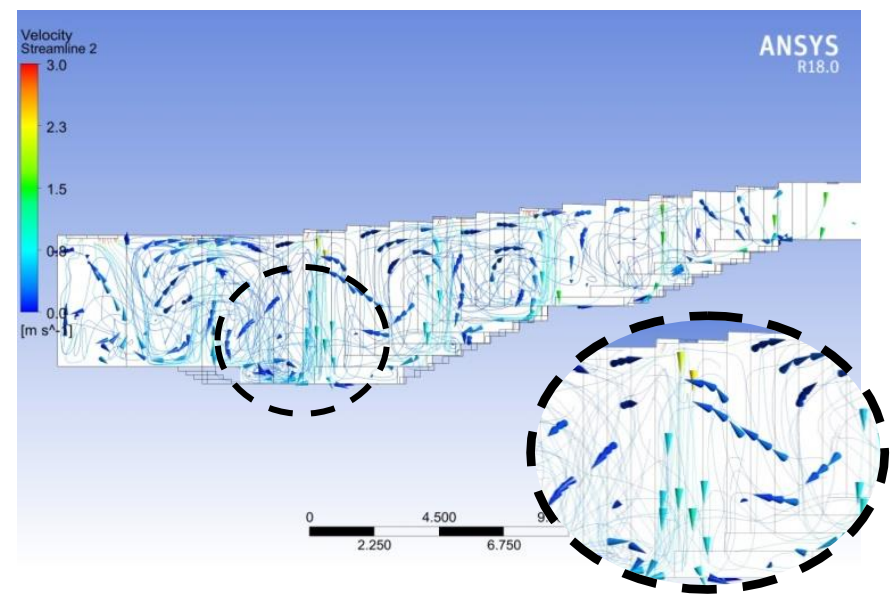

Figure 10. Hasil simulasi pola aliran udara dalam a uditorium

In the figure above, show the pattern of airflow that moves in all directions. This is in accordance with the working principle of mixing ventilation which aims to mix all air contained in the room. In the same picture is also seen air moving down from the diffuser with high speed. It is marked with a yellowish-colored arrow and pointed down (see the black circle in Fig. 10).

\subsection{Design of Displacement Ventilation Distribution System}

The following design procedures for displacement ventilation are based on ASHRAE's research on the 949 project by Chen, Glicksman, Yuan, Hu and Yang in 1999 and on the scheme of procedures made by Chen and Glicksman in 2003 (Price Engineer's HVAC Handbook, 2016).

As is known, the auditorium has a capacity of 472 people with power generated by the occupants assumed at 75 watts per person. The expected temperature in the auditorium in accordance with SNI 6390: 2011 standard is $24^{\circ} \mathrm{C}$. The auditorium floor area is $612.5 \mathrm{~m}^{2}$ and the volume of the room is $2,189,7 \mathrm{~m}^{3}$. The auditorium utilizes $2 \mathrm{LCD}$ projector units with assumed power of 60 Watts per unit, while for laptops it is assumed to be $40 \mathrm{Watt}$. For lighting, the power used is assumed to be $25 \mathrm{~W} / \mathrm{m}^{2}$. Heat and density in the auditorium is assumed to be $1,007 \mathrm{~kJ} /(\mathrm{kgK})$ and 1.2 $\mathrm{kg} / \mathrm{m}^{2}$.

- Step 1: Determine the total amount of cooling load.

$$
\begin{aligned}
\mathrm{q}_{\mathrm{t}} & =\mathrm{q}_{\mathrm{oe}}+\mathrm{q}_{1}+\mathrm{q}_{\mathrm{ex}} \\
\mathrm{q}_{\mathrm{oe}} & =(472 \times 75 \mathrm{~W})+2(60) \mathrm{W}+40 \mathrm{~W} \\
& =35.560 \mathrm{~W} . \\
\mathrm{q}_{1} & =25 \mathrm{~W} / \mathrm{m}^{2} \times 612,5 \mathrm{~m}^{2}=15.312,5 \mathrm{~W} . \\
\mathrm{q}_{\mathrm{ex}} & =0 \mathrm{~W} \\
\mathrm{q}_{\mathrm{t}} & =50.872,5 \mathrm{~W} .
\end{aligned}
$$

Total cooling load for the auditorium is 50,872.5 Watt.

- Step 2: Determine the airflow rate in the auditorium

$$
\begin{aligned}
Q_{D V} & =\frac{0.295 \mathrm{q}_{\mathrm{oe}}+0.132 \mathrm{q}_{1}+0.185 \mathrm{q}_{\mathrm{ex}}}{\rho \mathrm{c}_{\mathrm{\rho}} \triangle \mathrm{t}_{\mathrm{hf}}} \\
\mathrm{Q}_{\mathrm{DV}} & =\frac{0,295(35.560)+0,132(15.312,5)+0}{(1,2)(1,007)(2)} \\
& =5.176,87 \mathrm{~L} / \mathrm{s}
\end{aligned}
$$

- Step 3: Determine the rate of fresh air flow in the auditorium

$$
\begin{aligned}
& \mathrm{Q}_{\mathrm{oz}}=\frac{\mathrm{R}_{\mathrm{p}} \mathrm{P}_{\mathrm{z}}+\mathrm{R}_{\mathrm{a}} \mathrm{A}_{\mathrm{z}}}{\mathrm{E}_{\mathrm{z}}} \\
& \mathrm{Q}_{\mathrm{oz}}=\frac{2,5(472)+0,3(612,5)}{1,2} \\
& \mathrm{Q}_{\mathrm{oz}}=1.136,45 \mathrm{~L} / \mathrm{s}
\end{aligned}
$$

The total volume of air supply is the maximum value between $\mathrm{QDv}_{\mathrm{Dv}}$ and $\mathrm{Q}_{\mathrm{oz}}$.

$$
\mathrm{Qs}=\max \left[\mathrm{Q}_{\mathrm{DV}}, \mathrm{Q}_{\mathrm{oz}}\right]=5.176,87 \mathrm{~L} / \mathrm{s}
$$


- Step 4: Determine the temperature of the air supply

$$
\begin{aligned}
& \mathrm{t}_{\mathrm{s}}=\mathrm{t}_{\mathrm{sp}}-\triangle \mathrm{t}_{\mathrm{hf}} \frac{\mathrm{A}_{\mathrm{z}} \mathrm{q}_{\mathrm{t}}}{2,456 \mathrm{Q}_{\mathrm{s}}^{2}+1,08 \mathrm{~A} \mathrm{Q}} \\
& \mathrm{t}_{\mathrm{s}}=24-2-\frac{612,5(50872,5)}{0,584(5176,87)^{2}+1,208(612,5)(5176,87)} \\
& \mathrm{t}_{\mathrm{s}}=20,4^{\circ} \mathrm{C}
\end{aligned}
$$

- Step 5: Determine the air temperature back

$$
\begin{aligned}
& \mathrm{t}_{\mathrm{e}}=\mathrm{t}_{\mathrm{s}}+\frac{\mathrm{q}_{\mathrm{t}}}{1,208(\mathrm{Qs})} \\
& \mathrm{t}_{\mathrm{e}}=20,4+\frac{50.872,5}{1,208(5.176,87)} \\
& \mathrm{t}_{\mathrm{e}}=28,5^{\circ} \mathrm{C}
\end{aligned}
$$

If a fresh air velocity corresponding to the comfort standard is $0.25 \mathrm{~m} / \mathrm{s}$, then for an air supply volume of $5176.87 \mathrm{~L} / \mathrm{s}$, it is necessary to have a diffuser with a surface area of $20.7 \mathrm{~m}^{2}$ (1 L equivalent to $\left.0.001 \mathrm{~m}^{3}\right)$.

The selected diffuser type is a wall mounted diffuser because of its embedded position on the lower wall. This diffuser will not block the viewer's view of the stage, and is also freely placed anywhere; be it on the stage area or on the storied audience area.

With a surface dimension of $0.3 \mathrm{~m} \times 0.6 \mathrm{~m}$, the surface area for one diffuser unit is $0.18 \mathrm{~m}^{2}$. Means the number of diffuser required is 115 units.

\section{Conclusions}

- Based on the analysis of the measurements taken when the room is empty, without visitors and without any activity in the room, we can know that the air distribution system in the auditorium is mixing ventilation, with the following considerations: (1) diffuser and exhaust placement which is at the top of the room; (2) air is supplied at high speed, ie $2.7 \mathrm{~m} / \mathrm{s}$; and (3) when the diffuser or exhaust is turned on, the level of $\mathrm{CO}_{2}$, air temperature and humidity in the room become uniformly tended at every measured point.

- The effect of the air distribution system present in the auditorium on the indoor air quality level is not good enough. Mixing ventilation proved inadequate to overcome air quality problems within the auditorium. The concentration of $\mathrm{CO}_{2}$ gas during the activity can reach 1993 ppm, well above the maximum threshold set by ASHRAE, which is $1000 \mathrm{ppm}$. Air quality is closely related to the health and comfort of visitors. High levels of $\mathrm{CO}_{2}$ gas concentration can adversely affect visitors' health and comfort. This shows that the selection of the type of air distribution system used in the auditorium, has a considerable influence on the air quality level contained in the space.
- Air distribution system in the auditorium can provide air flow in a comfortable space and simultaneously avoiding the buildup of $\mathrm{CO}_{2}$ gas is a distribution displacement ventilation system, with an indoor air temperature setting of $24^{\circ} \mathrm{C}$, the air supply velocity coming from the diffuser is $0.25 \mathrm{~m} / \mathrm{s}$, the total surface area of the diffuser is $20.7 \mathrm{~m}^{2}$, and the airflow pattern is likely to move upwards.

Based on the results of this research, it is recommended: (1) Utilizing the detector level $\mathrm{CO}_{2}$ gas concentration especially for the closed room. This is done to determine the level of indoor air quality so that action can be taken if the level of air quality in the room has passed the maximum threshold set by ASHRAE, which is 1000 ppm; (2) Reorganize the number and placement of the exhaust contained in the auditorium. This needs to be done to obtain better air quality for audience within the auditorium. Based on the results of the measurements taken during the activities in the auditorium, there was a significant influence between the number and the placement of exhaust on air quality in space. It can also be a concern as well as material for further research; (3) There needs to be coordination between the auditorium management and the event committee on the duration of activities that can take place in the auditorium. Based on the results of research that has been done, it is known that there is a considerable influence between the duration of activities that take place on air quality in space. The longer the activity takes place in the auditorium, the level of $\mathrm{CO}_{2}$ gas concentration also increased. Hence, it is consider that a break time is needed. This is useful in addition to visitors to be able to break, also for air quality in the room. Diffuser and exhaust can work to remove the heat and pollutant to the maximum when the room is emptied, so that air quality can be back to normal when the activity resumed.

\section{References}

[1] Kavgic M., Mumovic D., Stevanovic Z., Young A. (2007), Analysis of Thermal Comfort and Indoor Air Quality In A Mechanically Ventilated Theatre.

[2] Fong M. L, Lin Z.; Fong K. F., Chow T. T., Yao T. (2010). Evaluation of thermal comfort conditions in a classroom with three ventilation methods, Hongkong, City University of Hongkong.

[3] Satwiko, Prasasto(2009), Fisika Bangunan, Yogyakarta

[4] ASHRAE, (2002), Indoor Air Quality : A Guide to Understanding ASHRAE Standard 62-2001.

[5] Price Engineer's HVAC Handbook (2016), Engineering Guide Displacement Ventilation.

[6] SNI 03-6572-2001, Tata Cara Perancangan Sistem Ventilasi dan Pengkondisian Udara pada Bangunan Gedung. 